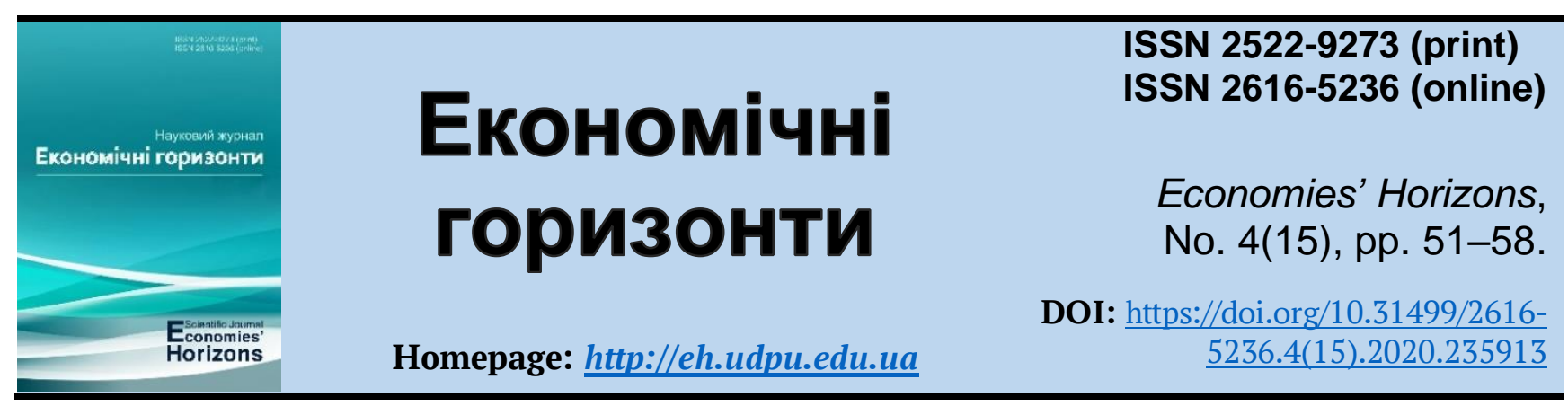

UDC 331.556:338.1

\title{
Migration process: Impact on sustainable development of the national economy
}

\author{
Denys V. Pudryk ${ }^{1}$, Cand. Ec. Sc.
}

Received: 22 October 2020 Accepted: 5 December 2020

\begin{abstract}
Pudryk, D. V. (2020), "Migration process: Impact on sustainable development of the national economy", Economies' Horizons, no. 4(15), pp. 51-58, doi: https://doi.org/10.31499/2616$\underline{5236.4(15) .2020 .235913}$
\end{abstract}

Abstract. Purpose of the research. The paper aims to analyse the relationship between migration and the sustainable development of the countries, identifying the tendencies evolutions of the migration theory in the context of three dimensions: content, geographical and historical. Methodology. The description of tendencies of the evolution of the theory of management of migration processes was done with bibliometric analysis tools. For this purpose, the author generated the meta-data of scientific publications on the researched issues from Scopus. The results of the bibliometric analysis were visualised using VOSviewer. To determine the relationship between migration and sustainable development of the country, a nonparametric measure of Spearman's correlation was calculated using the EViews. Results. According to bibliometric analysis, the main directions of scientific research on migration issues are determined. The development of the theory of management of migration processes by geographical and temporal dimensions is described. The following scientific clusters could be highlighted: the most significant cluster (red) - focuses on the general aspects of the migration; green cluster - focuses on the demography and cultural as core factors that influenced migration; blue cluster - focuses on the impact of migration policy and governance efficiency on the migration; yellow cluster - linking among gender factor, economic and social development, and migration. It was determined that the latest publications focus on the study of relationships among migration processes and the effectiveness of sustainable development goals. Practical meaning. The author empirically proved the existence of a correlation between migration and sustainable development of the country. Prospects for further research. The results justified the necessity to test the hypothesis of long-term causal links between migration and indicators of sustainable development of the country.

Keywords: emigrants, immigrants, economic growth, migration, sustainable development.

JEL Classification: F22, O15, R23, Q01.

Number of references: 13; number of tables: 3; number of figures: 5; number of formulas: $\mathbf{0 .}$

\footnotetext{
${ }^{1}$ The Customer Service in Odesa, Ukraine; e-mail: pudrykdenys.n@gmail.com.
} 


\title{
Міграційні процеси: вплив на сталий розвиток національної економіки
}

\author{
Денис Валерійович Пудрик ${ }^{1}$, к. е. н.
}

Стаття надійшла: 22.10.2020 Стаття прийнята: 05.12.2020
Pudryk, D. V. Migration process: Impact on sustainable development of the national economy. Економічні горизонти. 2020. № 4(15). C. 51-58. DOI: 10.31499/2616$\underline{5236.4(15) .2020 .235913}$

Анотація. Мета дослідження. Стаття присвячена визначенню взаємозв'язку між обсягами міграції та сталим розвитком країни, а також опису тенденцій еволюції теорії управління міграційними процесами у розрізі трьох вимірів: змістовному, географічному та часовому. Методологія. Опис тенденцій еволюції теорії управління міграційними процесами здійснено з використанням інструментарію бібліометричного аналізу. Для цього згенеровано вибірку мета-даних наукових публікацій з досліджуваної проблематики з наукометричної бази даних Scopus. Результати бібліометричного аналізу візуалізовано з використанням VOSviewer. Для визначення взаємозв'язку між обсягами міграції та сталим розвитком країни розраховано непараметричну міру кореляції Спірмена з використанням інструментарію Eviews. Результати. За результатами бібліометричного аналізу визначено основні напрями наукових досліджень 3 міграційної проблематики. Описано розвиток теорії управління міграційними процесами за змістовним, географічним та часовим вимірами. У статті виокремлено наступні наукові кластери: найбільший кластер (червоний) - сфокусований на вивченні загальних аспектів міграції); зелений кластер - зосереджений на досліджені демографічних та культурних факторі, що впливають на міграційні процеси в країні; блакитний кластер - сфокусований на визначенні взаємозв'язку між міграційною політикою та ефективністю державного управління; жовтий кластер - оцінювання впливу гендерного фактору, рівня економічного та соціального розвитку країни на міграційні процеси. Визначено, що останні публікації фокусуються на дослідженні питань взаємозалежності міграційними процесами та ефективністю досягнення задекларованих цілей сталого розвитку країни. Практичне значення. Автором емпірично обгрунтовано наявність кореляційного зв'язку між обсягами міграції та сталим розвитком країни. Перспективи подальших досліджень. Результати дослідження підтверджують необхідність перевірки гіпотези про наявність довгострокових причинно-наслідкових зв’язків між обсягами міграції та індикаторами сталого розвитку країни.

Ключові слова: емігранти, іммігранти, економічне зростання, міграція, сталий розвиток.

Кількість джерел: 13; кількість таблищь:3; кількість рисунків: 5; кількість формул: 0.

\section{Introduction.}

Human and intellectual capital are the catalysator of the country's sustainable development. In this case, the developed countries develop attractive conditions for highly skilled professionals. In less developed countries, the outflow of workers is the issues which the brain drains. As a consequence, it limits of country's sustainable development. Considering the Agenda of sustainable development goals (SDGs) 2030 for Ukraine, the following goals are in priorities:

Goal 1: No poverty.

Goal 3: Good health and well being.
Goal 4: Quality education.

Goal 8: Decent work and economic growth.

Goal 9: Industry, innovation, and infrastructure.

Goal 11: Sustainable cities and community.

Noting, all SDGs mentioned above relate close to the migration process in Ukraine. Despite the most European countries (where the migration process enriches the total number of the population and leads to its rejuvenation) in Ukraine, the long-term decline of the birth rate is enforced by the outflow of the young

${ }^{1}$ Одеська митниця; e-mail: pudrykdenys.n@gmail.com. 
generation. In this case, for Ukraine, it is actually to provide equal conditions for workforces, guarantee equal access to medical services, develop the workplaces and adequate salary. It allows restricting the brain drains and accumulate the human and intellectual capital to enforce the country's sustainable development.

\section{Literature review.}

The scientific community has a robust background in the analysis of the migration process, causes and consequences. Thus, using the regression analysis, the paper (Brown and
Longbrake, 1970) analysed the intermigration process in the USA and identified the critical incentive indicators for migration. J. Hudson (1970) analysed the linking between economic growth and migration compare to the metropolis and non-metropolitan cities. Using the modification of the Lotka-Volterra model, J. Hudson (1970) confirmed that strict economic growth and migration process could not allow a stable country's development. The findings confirmed that the numbers of papers on migration increased from 2007 (Figure 1).

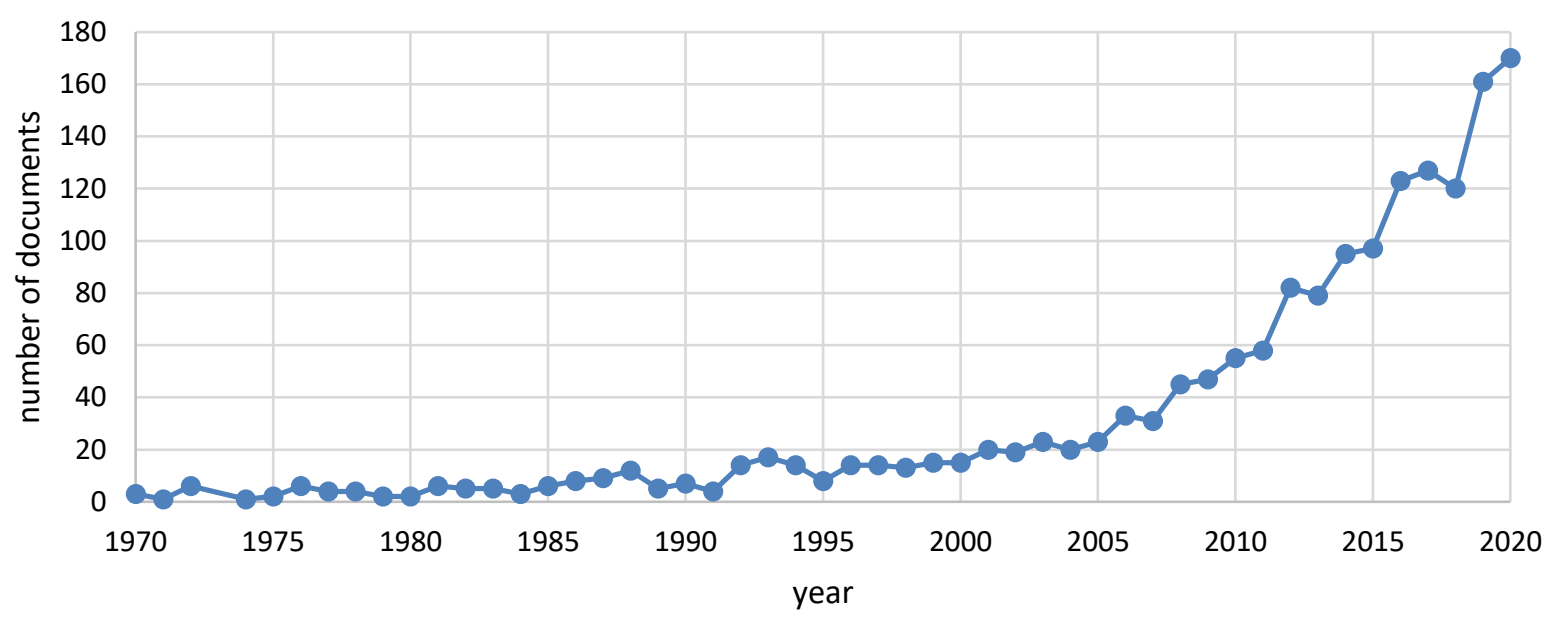

Fig. 1. The publication dynamic on migration issues in the Scientific Journal which indexing by Scopus

Source: Author's development.

Considering the findings, the most cited paper (500 citations) was published by J. Taylor (1999). J. Taylor proved that migration stimulates money transfers, which positively affect the country's economic growth. D. Massey, L. Goldring and J. Durand (1994) proved that any social and economic disparities provoked migration in the country. In the investigation, they analysed 19 Mexican communities. C. Fan (2002) confirmed that the countries with transitional economies should develop attractive conditions for labour forces (300 citations). Top-10 cited papers presented in Table 1.

The findings confirmed that the scientists analysed the migration from different points of view. Mainly, the scientists analysed the social and economic conditions as a core indicator that influenced migration. On the other side, high-rate migration is the biggest issue for countries with transitional economies.

\section{Methodology.}

The bibliometric analysis was used for identifying the core scientific clusters on the migration investigation. The bibliometric analyses of the 16,330 papers from databases Scopus were selected on the Busines and Economics subject areas. VOSviewer was used for the visualising of the bibliometric analyses.

The mathematical and statistical methods were used for checking the relationships between the SDG Index, the crude rate of net migration plus adjustment, GDP. The object of investigation Ukraine and Visegrad countries. The date for analysis was generated from the Sustainable Development Report, World Development Indicators. 
Table 1. The most cited papers on migration issues in the Scientific Journal which indexing by Scopus

\begin{tabular}{|c|c|c|c|}
\hline Authors & Title & Journal & Hypothesis \\
\hline J. Taylor (1999) & $\begin{array}{l}\text { The new economics of labour } \\
\text { migration and the role of remit- } \\
\text { tances in the migration process }\end{array}$ & $\begin{array}{l}\text { International } \\
\text { Migration }\end{array}$ & $\begin{array}{l}\text { linking among migration } \\
\text { stimulate and money } \\
\text { transfers }\end{array}$ \\
\hline $\begin{array}{l}\text { D. Massey, } \\
\text { L. Goldring and } \\
\text { J. Durand (1994) } \\
\end{array}$ & $\begin{array}{l}\text { Continuities in transnational mi- } \\
\text { gration: An analysis of nineteen } \\
\text { Mexican communities }\end{array}$ & $\begin{array}{l}\text { American Jour- } \\
\text { nal of Sociology }\end{array}$ & $\begin{array}{c}\text { social and economic } \\
\text { changes lead to } \\
\text { increasing migration } \\
\end{array}$ \\
\hline C. Fan (2002) & $\begin{array}{l}\text { The elite, the natives, and the } \\
\text { outsiders: Migration and labour } \\
\text { market segmentation in urban } \\
\text { China }\end{array}$ & $\begin{array}{l}\text { Annals of the } \\
\text { Association of } \\
\text { American } \\
\text { Geographers }\end{array}$ & $\begin{array}{l}\text { The work conditions in- } \\
\text { fluence migration }\end{array}$ \\
\hline $\begin{array}{l}\text { S. Kanaiaupuni } \\
\qquad(2000)\end{array}$ & $\begin{array}{l}\text { Reframing the migration ques- } \\
\text { tion: An analysis of men, } \\
\text { women, and gender in Mexico }\end{array}$ & Social Forces & $\begin{array}{l}\text { The gender difference } \\
\text { influence migration }\end{array}$ \\
\hline $\begin{array}{l}\text { Y. P. Wang, } \\
\text { Y. Wang, J. Wu } \\
\quad(2009)\end{array}$ & $\begin{array}{l}\text { Urbanisation and informal de- } \\
\text { velopment in china: Urban vil- } \\
\text { lages in Shenzhen }\end{array}$ & $\begin{array}{l}\text { International } \\
\text { Journal of Urban } \\
\text { and Regional } \\
\text { Research }\end{array}$ & $\begin{array}{l}\text { Linking among migration } \\
\text { and informal village } \\
\text { development }\end{array}$ \\
\hline S. Haug (2008) & $\begin{array}{l}\text { Migration networks and migra- } \\
\text { tion decision-making }\end{array}$ & $\begin{array}{l}\text { Journal of Eth- } \\
\text { nic and Migra- } \\
\text { tion Studies }\end{array}$ & $\begin{array}{l}\text { Relationship between so- } \\
\text { ciological and economic } \\
\text { aspects of migration }\end{array}$ \\
\hline $\begin{array}{l}\text { A. Gallagher } \\
\text { (2001) }\end{array}$ & $\begin{array}{l}\text { Human rights and the new UN } \\
\text { protocols on trafficking and mi- } \\
\text { grant smuggling: A preliminary } \\
\text { analysis }\end{array}$ & $\begin{array}{l}\text { Human Rights } \\
\text { Quarterly }\end{array}$ & $\begin{array}{l}\text { Normative regulation } \\
\text { influenced migration }\end{array}$ \\
\hline $\begin{array}{l}\text { A. Stockdale } \\
\text { (2006) }\end{array}$ & $\begin{array}{l}\text { Migration: Pre-requisite for rural } \\
\text { economic regeneration? }\end{array}$ & $\begin{array}{l}\text { Journal of Rural } \\
\text { Studies }\end{array}$ & $\begin{array}{l}\text { Migration has a positive } \\
\text { effect on human capital } \\
\text { in the country }\end{array}$ \\
\hline J. Chen (2011) & $\begin{array}{l}\text { Internal Migration and Health: } \\
\text { Re-Examining the Healthy } \\
\text { Migrant Phenomenon in China }\end{array}$ & $\begin{array}{l}\text { Social Science } \\
\text { and Medicine }\end{array}$ & $\begin{array}{l}\text { Linking among self-rated } \\
\text { physical health, psycho- } \\
\text { logical distress, and mi- } \\
\text { gration experience, con- } \\
\text { trolling for sociodemo- } \\
\text { graphic characteristics }\end{array}$ \\
\hline K. Roberts (1997) & $\begin{array}{l}\text { China's "tidal wave" of migrant } \\
\text { labour: What can we learn from } \\
\text { undocumented Mexican migra- } \\
\text { tion to the United States? }\end{array}$ & $\begin{array}{l}\text { International } \\
\text { Migration } \\
\text { Review }\end{array}$ & $\begin{array}{l}\text { Linking among the mi- } \\
\text { gration process, the eco- } \\
\text { nomic and social position } \\
\text { of migrants }\end{array}$ \\
\hline
\end{tabular}

Source: Author's development.

\section{Research objectives.}

The paper aims to identify the core directions of the impact of the migration process on the sustainable development of the national economy.

\section{Results and discussions.}

Considering the analysis results (Figure 2 ), the scientists from the USA have been started to analyse the migration before 2010. It justified that fact the USA was the first countries which felt issues with migration. Besides, in Ukraine, the analysis of the issues of migration was activated after the 2017 year. It could be explained by the deepening of economic and political instability in the country and open beaneries for free movement between the EU and Ukraine. 


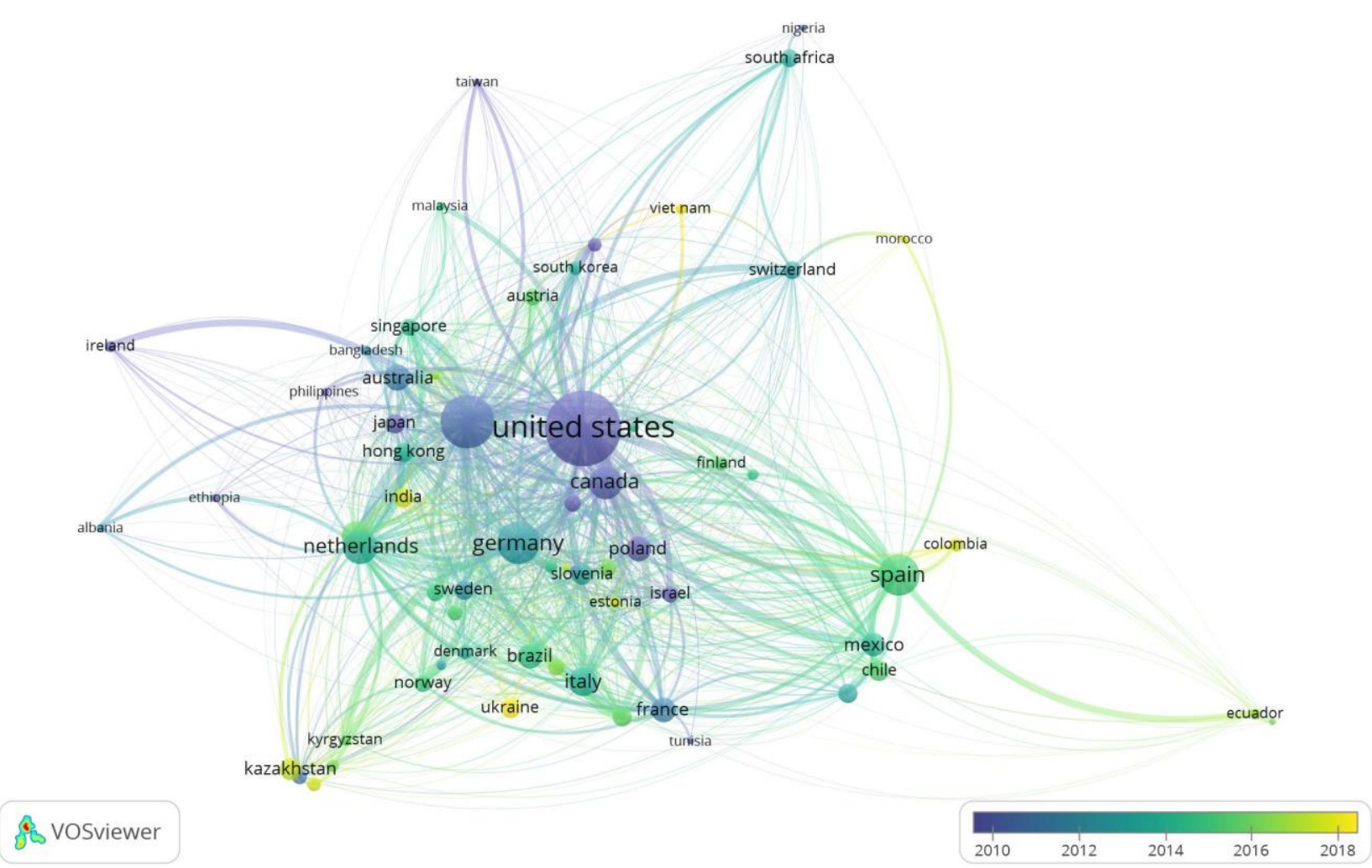

\section{Fig. 2. The findings of bibliometric analysis of the publications which focused on migra- tion (based on Scopus data)}

Source: Author's development using the VOSviewer.

The findings of bibliometric analysis allow identifying the core directions of the migration investigation (Figure 3). Thus, the following scientific clusters could be highlighted: the most significant cluster (red) - focuses on the general aspects of the migration (contains 106 items); green cluster - focuses on the demography and culture as core factors which influenced migration (contains 41 items); blue cluster - focuses on the impact of migration policy and governance efficiency on the migration process (contains 37 items); yellow cluster - linking among gender factor, economic and social development, and migration.

The overlay visualisation of the bibliometric analysis confirmed that firstly (19902000), the scientists analysed the demography and culture as the determinants of the migration (green cluster in Figure 3 and navy-blue Figure 4). During 2000-2010 the researchers were analysing the impact of government efficiency on the migration process. After 2010 the papers focus on cultural, human rights, nationalism education as the dimensions of migration (light green and yellow colour in Figure 4).

Besides, considering the findings after 2015 , the scientists have been analysed the relationships between sustainable development and migration process in the country. SDG Index allows comparing the countries on their success on the way of achieving sustainable development goals. During the 2016-2019 years among the Visegrad countries, Czech Republic had the highest values of SDG Index (2019 - 80.7, Figure 5). Considering the official report, Ukraine has the growth dynamic of SDG Index score (in 2016 - 66.39 and 2019 72.8). At the same time, Ukraine has the lowest value of the SDG Index among analysed countries. 


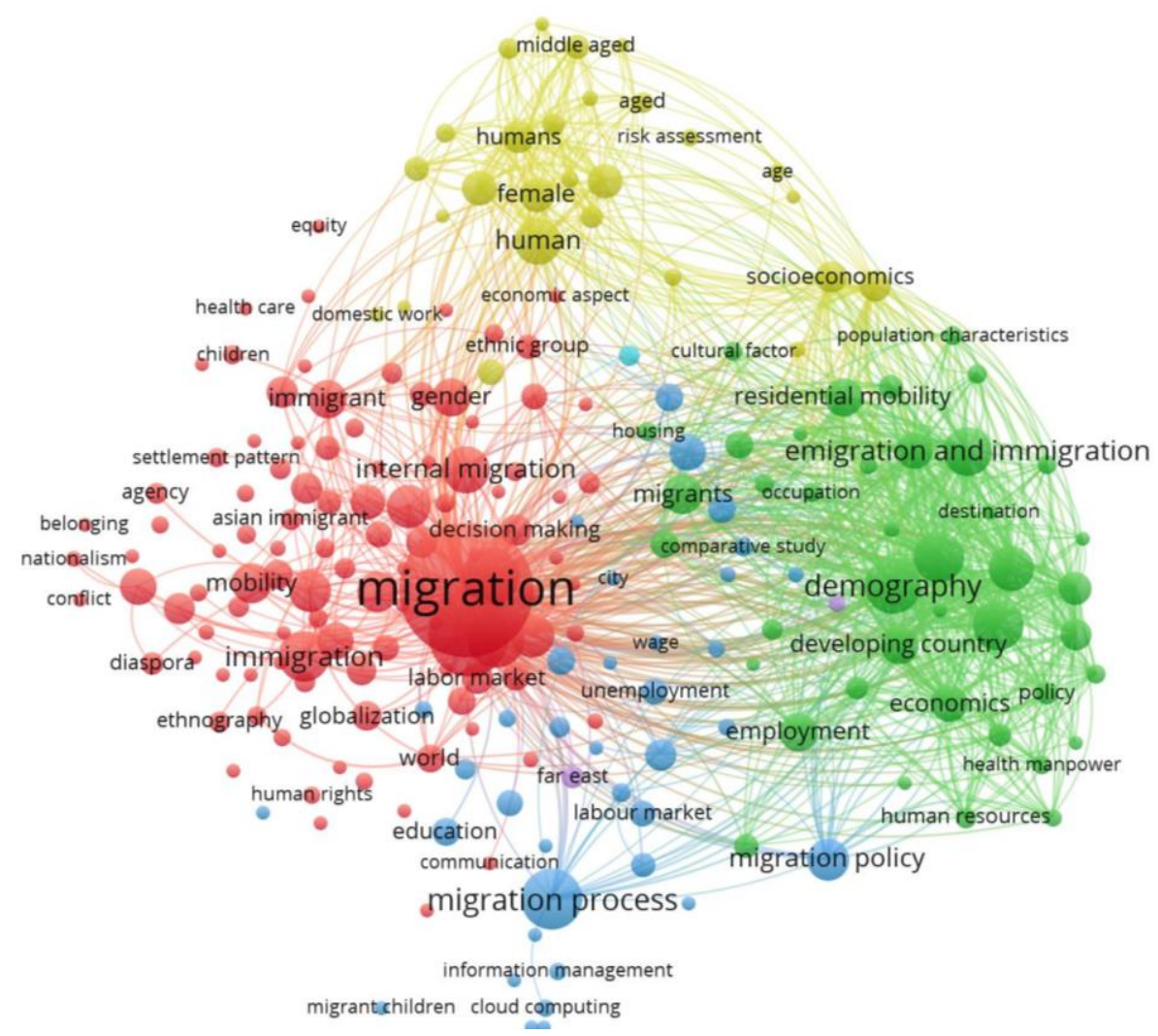

Fig. 3. The findings of bibliometric analysis of the publications which focused on migration (based on Scopus data)

Source: Author's development using the VOSviewer.

\& VOSviewer

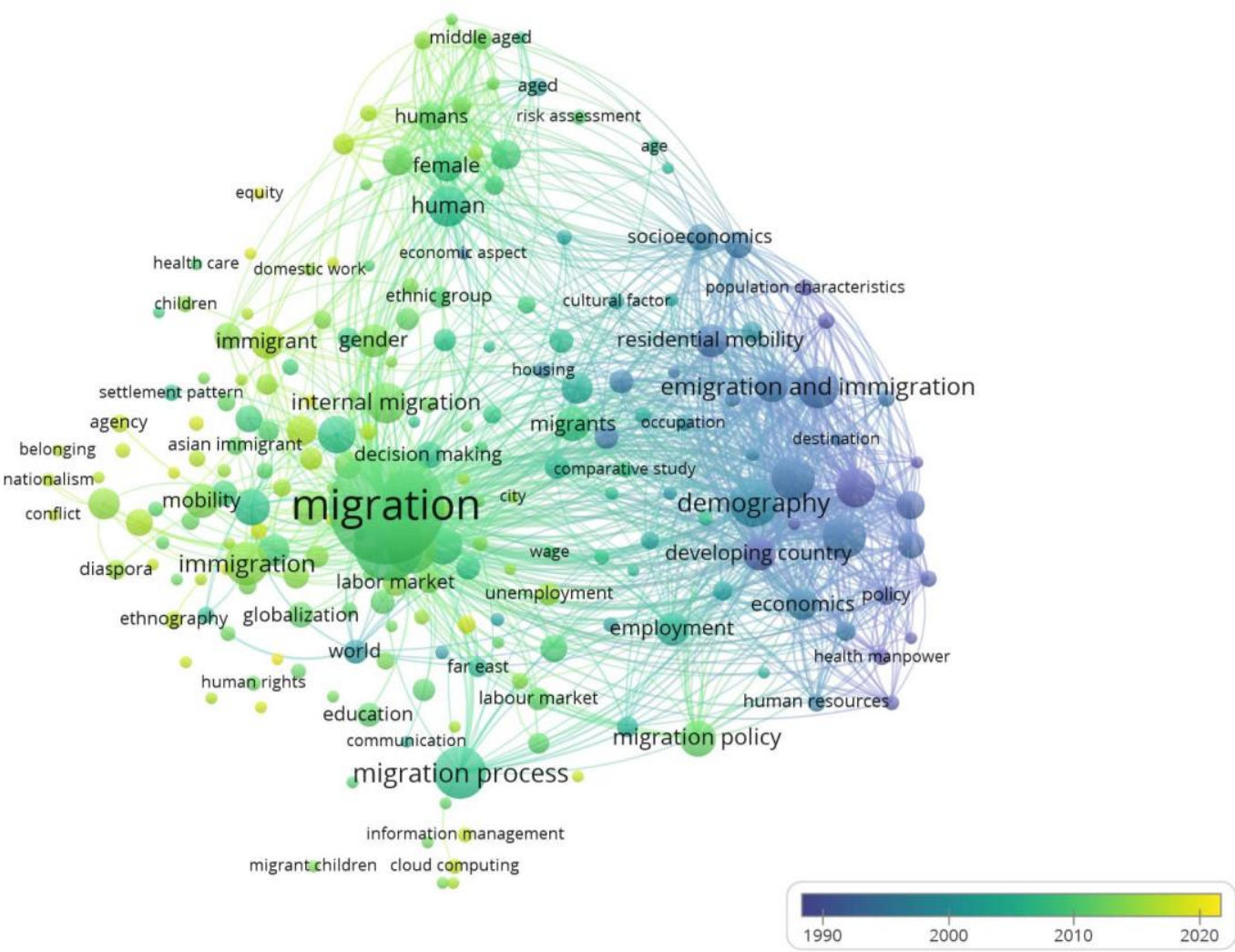

Fig. 4. The overlay visualisation of bibliometric analysis of the publications which focused on migration (based on Scopus data) under the historical dimension Source: Author's development using the VOSviewer. 


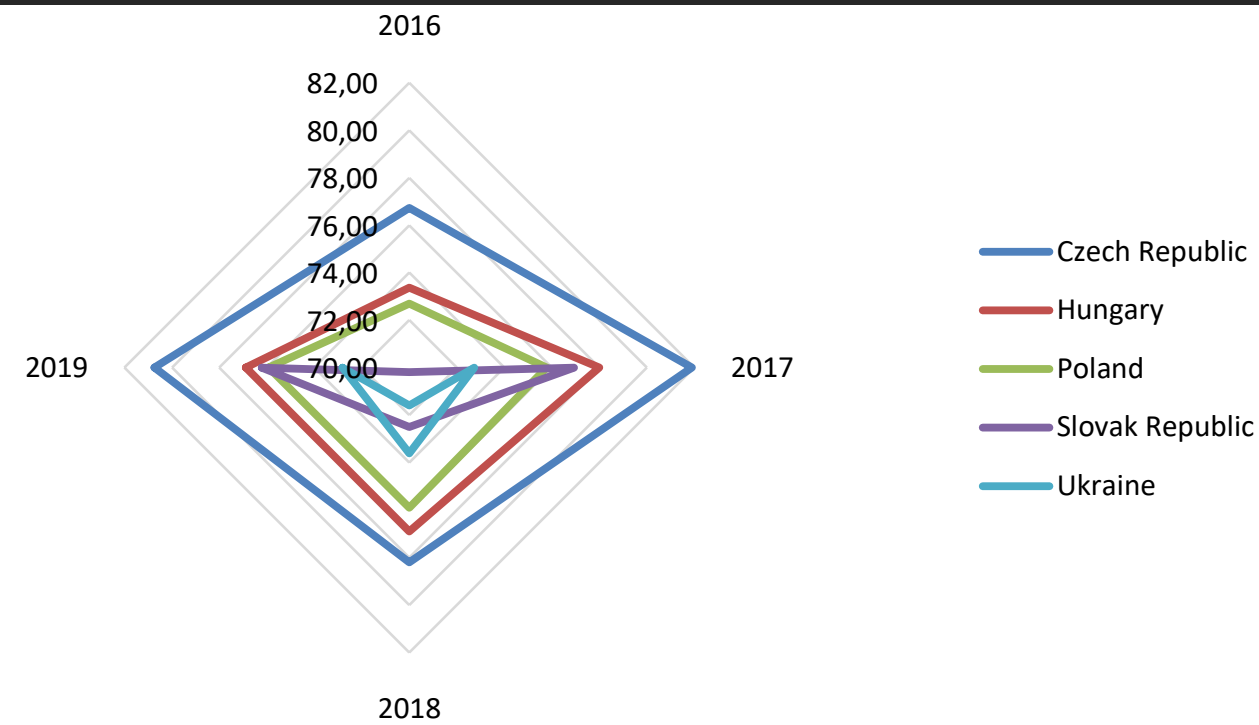

Fig. 5. The dynamic of SDG index (score) among Ukraine and Visegrad countries (2016-2019)

Source: Author's development based on (Sachs et al., 2019).

The comparison analysis of migration highest value crude rate of net migration plus among Ukraine and Visegrad countries adjustment (Figure 6). showed that Chechia and Hungary have the

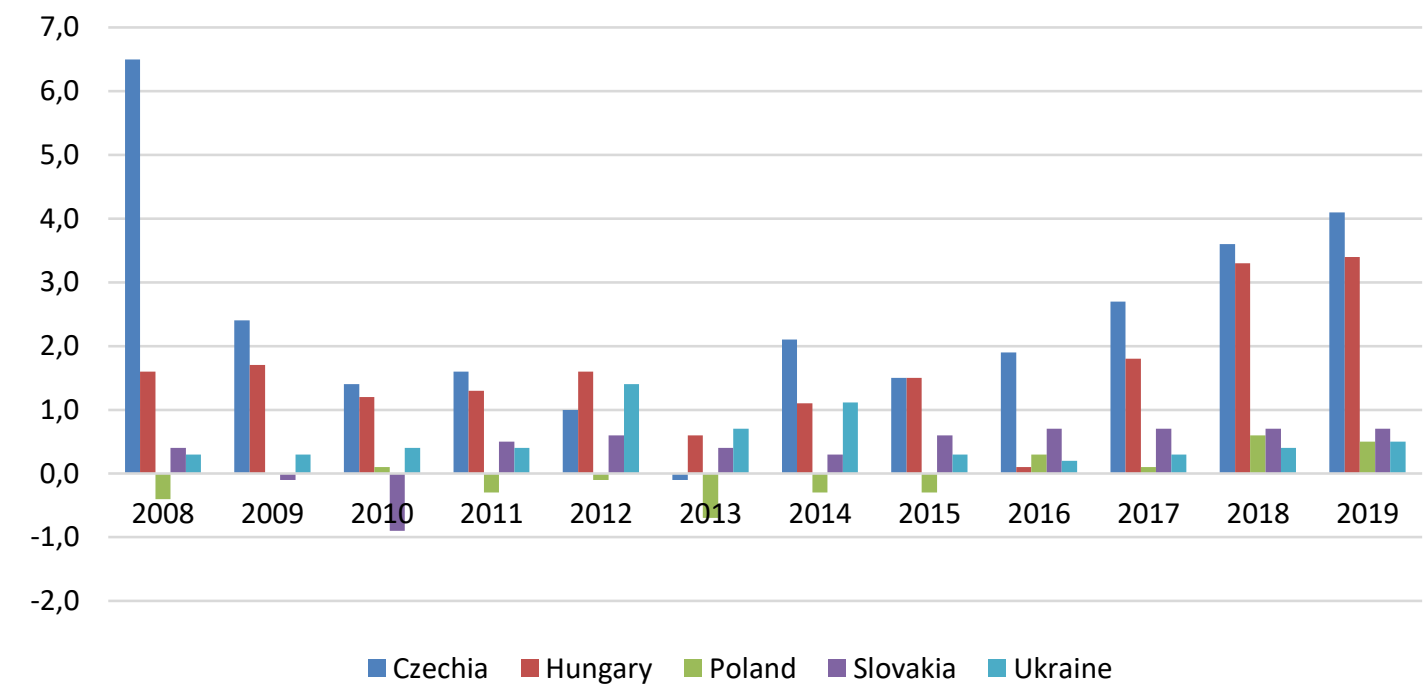

Fig. 6. The dynamic of the crude rate of net migration plus adjustment among Ukraine and Visegrad countries (2008-2019)

Source: Author's development based on (Sachs et al., 2019).

In addition, Chechia and Poland had the highest value of GDP in the 2018-2019 years

The findings of descriptive statistics showed in Table 2.

The results of nonparametric correlation analysis (Table 3) between GDP, net migration plus adjustment and SDG Index confirmed the high value of correlation among them with probability at $1 \%$.
Table 2. Descriptive statistics of GDP, net migration plus adjustment (MIGR) and SDG Index (SDG)

\begin{tabular}{|l|c|c|c|}
\hline & GDP & MIGR & SDG \\
\hline Mean & $29,428.67$ & 1.33 & 75.10 \\
\hline Median & $31,371.40$ & 0.70 & 75.91 \\
\hline Maximum & $44,286.95$ & 4.10 & 81.90 \\
\hline Minimum & $11,148.20$ & 0.10 & 66.39 \\
\hline
\end{tabular}

Source: Author's calculation. 
Table 3. The correlation matrix of GDP, net migration plus adjustment (MIGR) and SDG Index (SDG)

\begin{tabular}{|c|c|c|c|}
\hline & SDG & MIGR & GDP \\
\hline SDG & 1 & & \\
\hline MIGR & $\begin{array}{c}0.74 \\
(0.0002)^{*}\end{array}$ & 1 & \\
\hline GDP & $\begin{array}{c}0.75 \\
(0.0001)^{*}\end{array}$ & $\begin{array}{c}0.77 \\
(0.0001)^{*}\end{array}$ & 1 \\
\hline
\end{tabular}

* statistical significance at $1 \%$.

Source: Author's calculation.

\section{Conclusions.}

The analysis results showed that the scientists analysed migration from a different perspective, particularly under the gender, cultural, demography dimensions and efficiency of government policy. Besides, the new direction of the investigation is analysing linking sustainable development and migration in the country.

The results of correlation analysis confirmed that the changing of migration and GDP lead to changing of SDG Index. For further investigation, it is necessary to analyse the longterm casual relationship between migration and sustainable development of the country.

\section{References}

Brown, L. A. and Longbrake, D. B. (1970), "Migration flows in intraurban space: Place utility considerations", Annals of the Association of American Geographers, vol. 60, no. 2, pp. 368-384, doi: https://doi.org/10.1111/i.1467-8306.1970.tb00726.x

Chen, J. (2011), "Internal migration and health: Re-examining the healthy migrant phenomenon in China", Social Science and Medicine, vol. 72, no. 8, pp. 1294-1301, doi: https://doi.org/10.1016/j.socscimed.2011.02.016

Fan, C. C. (2002), “The elite, the natives, and the outsiders: Migration and labor market segmentation in urban China", Annals of the Association of American Geographers, vol. 92, no. 1, pp. 103-124, doi: https://doi.org/10.1111/1467-8306.00282

Gallagher, A. (2001), "Human rights and the new UN protocols on trafficking and migrant smuggling: A preliminary analysis", Human Rights Quarterly, vol.23, no. 4, pp. 975-1004, doi: https://doi.org/10.1353/hrq.2001.0059

Haug, S. (2008), "Migration networks and migration decision-making”, Journal of Ethnic and Migration Studies, vol. 34, no. 4, pp. 585-605, doi: https://doi.org/10.1080/13691830801961605

Hudson, J. C. (1970), "Elementary models for population growth and distribution analysis", Demography, no. 7, pp. 361-368, doi: https://doi.org/10.2307/2060155

Kanaiaupuni, S. M. (2000), "Reframing the migration question: An analysis of men, women, and gender in Mexico", Social Forces, vol. 78, no. 4, pp. 1311-1347, doi: https://doi.org/10.1093/sf/78.4.1311

Massey, D. S., Goldring, L. and Durand, J. (1994), "Continuities in transnational migration: An analysis of nineteen Mexican communities", American Journal of Sociology, vol. 99, no. 6, pp. 1492-1533, doi: https://doi.org/10.1086/230452

Roberts, K. D. (1997), “China’s "tidal wave” of migrant labor: What can we learn from Mexican undocumented migration to the united states?", International Migration Review, vol. 31, no. 2, pp. 249-293, doi: https://doi.org/10.2307/2547220

Sachs, J., Schmidt-Traub, G., Kroll, C., Lafortune, G. and Fuller, G. (2019), Sustainable Development Report 2019, Bertelsmann Stiftung and Sustainable Development Solutions Network (SDSN), New York, USA, $465 \mathrm{p}$.

Stockdale, A. (2006), "Migration: Pre-requisite for rural economic regeneration?”, Journal of Rural Studies, vol. 22, no. 3, pp. 354-366, doi: https://doi.org/10.1016/j.jrurstud.2005.11.001

Taylor, J. E. (1999), "The new economics of labour migration and the role of remittances in the migration process", International Migration, vol. 37, no. 1, pp. 63-88, doi: https://doi.org/10.1111/1468-2435.00066

Wang, Y. P., Wang, Y. and Wu, J. (2009), "Urbanisation and informal development in china: Urban villages in Shenzhen", International Journal of Urban and Regional Research, vol. 33, no. 4, pp. 957-973, doi: https://doi.org/10.1111/j.1468-2427.2009.00891.x

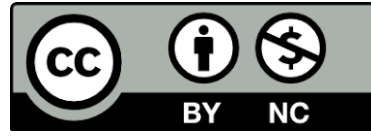

Цей твір ліцензовано на умовах Ліцензії Creative Commons «/з Зазначенням Aвторства - Некомерційна 4.0 Міжнародна» (CC BY-NC 4.0). This is an open access journal and all published articles are licensed under a Creative Commons "Attribution-NonCommercial 4.0 International" (CC BY-NC 4.0). 